\title{
Anthracnose disease response in the Burundi sorghum germplasm collection
}

\author{
John E. Erpelding \\ United States Department of Agriculture, Agricultural Research Service, Tropical Agriculture \\ Research Station, 2200 Pedro Albizu Campos Ave., Suite 201, Mayagüez, Puerto Rico \\ 00680-5470, USA
}

\begin{abstract}
The United States National Plant Germplasm System maintains 151 sorghum accessions from Burundi of which 148 accessions were evaluated for resistance to Colletotrichum sublineolum at the Tropical Agriculture Research Station in Isabela, Puerto Rico in replicated evaluations during the 2007 and 2008 growing seasons. For the 2007 experiment, 120 accessions showed a resistant response with 89 of these accessions rated as resistant in 2008. The resistant accessions showed reddening of inoculated leaves with no acervuli development, whereas accessions rated as susceptible showed acervuli development on inoculated leaves. Mean infection severity based on the percentage of infected leaf area for the susceptible accessions was $2 \%$ in 2007 and $2.5 \%$ for the 2008 experiment. Only four accessions showed an infection severity more than $10 \%$ and eight accessions showed a susceptible response across replications and growing seasons. Results of this study indicate that sorghum germplasm from Burundi is an important source of anthracnose resistance for sorghum improvement and that germplasm from regions of high annual rainfall is frequently associated with anthracnose resistance.
\end{abstract}

Keywords: African germplasm, anthracnose resistance, genetic resources, Sorghum bicolor

\section{INTRODUCTION}

Colletotrichum sublineolum ( $\mathrm{P}$. Henn. in Kabat and Bubák) is the fungal pathogen responsible for sorghum anthracnose and the disease is present in most sorghum producing regions worldwide (Thakur and Mathur, 2000; Crouch et al., 2006). Disease symptoms are generally observed on the leaves of the sorghum plant 30 to 40 days after seedling emergence. The pathogen can also infect the stalk, panicle, and seed (Thakur and Mathur, 2000; Hess et al., 2002). Symptoms of foliar anthracnose infection appear as circular, elliptical, or elongated lesions with acervuli (asexual fruiting bodies) formation in the center of the lesions. Grain yield losses ranging from 30 to $67 \%$ have been reported (Ali et al., 1987; Thomas et al., 1996). In Puerto Rico, plant death has been observed before maturing in highly susceptible germplasm accessions (Erpelding and Wang, 2007). Grain yield losses are typically associated with a reduction in grain weight due to poor grain development (Ali et al., 1987). The use of resistant varieties is the most practical method of managing the disease. In the United States, the use of resistant varieties is recommended for regions with climatic conditions favorable for the pathogen. Since the pathogen is highly variable and numerous pathotypes are present in most regions (Marley et al., 2001; Valério et al., 2005), pyramiding of host-plant resistance genes may be necessary to increase the longevity of resistant sources. Thus, additional resistant germplasm is needed to increase the genetic diversity of resistant genotypes available for sorghum improvement. Germplasm collections are important resources for the identification of anthracnose resistance and the sorghum germplasm collection from Burundi was evaluated during the 2007 and 2008 growing seasons in Puerto Rico to identify resistant genotypes.

\section{MATERIALS AND METHODS}

The sorghum (Sorghum bicolor (L.) Moench) germplasm collection from Burundi, East Africa maintained by the United States Department of Agriculture, Agricultural Research Service (USDAARS), National Plant Germplasm System is composed of 151 accessions (GRIN, 2007) of which 148 accessions were available for the disease evaluation. Seed samples were obtained from the USDA-ARS, Plant Genetic Resources Conservation Unit in Griffin, Georgia. The anthracnose evaluation was conducted at the USDA-ARS, Tropical Agriculture Research Station in Isabela, Puerto Rico. The experiment was planted in a randomized 
Agric. Biol. J. N. Am., 2010, 1 (6): 1119-1125

complete block design with each accession planted in a single row and replicated three times. Rows were $1.8 \mathrm{~m}$ in length with $0.9 \mathrm{~m}$ row spacing. A border row of an anthracnose susceptible sorghum genotype (PI 561472) was planted around each experimental field. Lorsban 15G (Chlorpyrifos) granular insecticide (Dow AgroSciences, Indianapolis, IN) was applied at a rate of $8 \mathrm{~kg} \mathrm{ha}^{-1}$ during planting to prevent seed loss from fire ants. No fertilizer was applied to the experiments and weeds were controlled with mechanical tillage and hand hoeing. Twelve control genotypes that show variation in anthracnose disease response were included in the evaluation and for which seed samples were available from the Plant Genetic Resources Conservation Unit. Five genotypes, NSL 4025 (Redlan), PI 533794 (SC110), PI 533991 (SC748), PI 534131 (SC30), and PI 595735 (SC1313), were included as resistant controls. The seven susceptible control genotypes included PI 173112, PI 211633, PI 533772 (SC271), PI 534157 (SC170), PI 561472 (Sureño), PI 564163 (BTx623), and PI 609251. The first experiment was planted on 1 November 2007 and the second experiment was planted 19 November 2008. Irrigation was applied two times before inoculation for each experiment and no irrigation was applied after inoculation. The 2007 experiment received $235 \mathrm{~mm}$ of rainfall before inoculation and $171 \mathrm{~mm}$ after inoculation with 33 rainfall events occurring after inoculation. For the 2008 experiment, $170 \mathrm{~mm}$ of rainfall was received before inoculation and a total of $153 \mathrm{~mm}$ was received during 33 rainfall events after inoculation.

Preparation of anthracnose cultures, field inoculation, and disease evaluation were as described by Erpelding and Prom (2006). Infected leaf samples were randomly collected from susceptible sorghum genotypes before each experiment to represent the pathotypes at the research site in Isabela, Puerto Rico and were used to establish cultures. Plants of each accession were inoculated with anthracnosecolonized sorghum seed at 34 days after planting. Disease evaluations were conducted using a 1 to 5 rating scale (Erpelding and Prom, 2006) where: 1 = no symptoms; 2 = reddening of inoculated leaves with no acervuli development; 3 = chlorotic lesions on inoculated leaves with acervuli development in the center of the lesions; $4=$ necrotic lesions with acervuli on inoculated leaves; and $5=$ coalescence of lesions on inoculated leaves with abundant acervuli and most leaves infected including the flag leaf. For the first experiment planted in 2007, plants were rated 12, 34, 50, and 64 days after inoculation. Disease ratings were conducted 16,30 , and 57 days after inoculation for the second experiment planted in 2008. Disease severity was also determined during each evaluation and was based on a visual rating of the percentage of infected leaf area for the susceptible plants within a row with approximately 20 plants evaluated in each row. Statistical analysis of the data was conducted using the disease severity from the final rating. The Statistix 9 software package (Analytical Software, Tallahassee, FL) was used for the analysis of variance and mean comparisons were conducted using Tukey's standardized range test at the $5 \%$ probability level.

\section{RESULTS}

The disease rating and mean infection severity data for the 148 sorghum accessions from the Burundi germplasm collection and 12 control genotypes are presented in Table 1. For the 2007 experiment, more accessions showed a resistant response with 120 accessions rated as resistant. Susceptibility to anthracnose was observed for 28 accessions with nine accessions showing no variation in disease ratings across replications. Ten accessions showed susceptibility across two replications and nine accessions showed a susceptible response in only one replication. Mean infection severity was generally less than $1 \%$ for accessions showing variation in disease response across replications. For the 28 susceptible accessions, mean infection severity was $2 \%$ and only one accession showed disease severity greater than $20 \%$. Mean infection severity was $5 \%$ for the nine accessions that showed a susceptible response across the three replications. Disease progression for the Burundi accessions was slow for the 2007 experiment (data not shown). One accession showed a susceptible response 12 days after inoculation and five accessions showed susceptibility 34 days after inoculation with one accession rated as susceptible across the three replications. Fifty days after inoculation, 14 accessions showed a susceptible response with five accessions rated as susceptible across the three replications.

For the 2008 experiment, a resistant response was observed for 89 accessions (Table 1). One accession was rated as highly susceptible with infection observed on the flag leaf. A susceptible response across the three replications was observed for 29 accessions, and 14 accessions showed susceptibility across two replications, while 16 accessions showed susceptibility in one replication. All accessions rated as susceptible for the 2007 experiment were rated as susceptible for the 2008 experiment. Mean infection 
severity was approximately $2.5 \%$ for the 59 accessions rated as susceptible in 2008. Four accessions showed a mean infection severity greater than $10 \%$ with a mean infection severity greater than $20 \%$ observed for one accession. For the 29 accessions showing susceptibility across the three replications, mean infection severity was 4.6\%. Disease progression was also slow for the 2008 experiment (data not shown). Seven accessions showed a susceptible response 16 days after inoculation with two accessions showing a susceptible response across the three replications. Thirty-four accessions showed a susceptible response 30 days after inoculation with susceptibility across replications observed for 12 accessions. All accessions showed reddening of inoculated leaves within 5 days after inoculation with acervuli development observed within 10 days on the susceptible control genotypes. Red spots were observed within 3 days after inoculation for the 2008 experiment and reddening of inoculated leaves was more prominent in 2008 , with a greater percentage of the inoculated leaf area showing the red response. For the majority of the susceptible accessions, acervuli development was only observed on inoculated leaves with no infection observed on noninoculated leaves.

The 12 control genotypes included in the evaluation showed the expected disease response (Table 1). With the exception of PI 534131, the resistant control genotypes showed red spots or reddening of inoculated leaves without acervuli development. PI 534131 typically shows nearly complete reddening of inoculated leaves and senescence of leaf margins with the development of acervuli on the leaf margins under favorable environmental conditions. A highly susceptible disease response was observed for the nine susceptible control genotypes. Infection of the flag leaf was generally observed within 30 days after inoculation and most of the susceptible control genotypes showed complete senescence of lower leaves at 60 days after inoculation. Mean infection severity for the nine susceptible control genotypes was higher (61\%) for the 2008 experiment as compared to the 2007 experiment (56\%). For both evaluations, PI 173112 and PI 609251 showed plant death at maturity with stalk breakage and lodging.

\section{DISCUSSION}

Most of the sorghum accessions from the Burundi germplasm collection showed resistance to anthracnose suggesting germplasm from this region is an important resource for the development of resistant varieties. Approximately $60 \%$ of the accessions showed no acervuli development and were rated as resistant. More than $90 \%$ of the accessions rated as susceptible showed mean infection severities of less than 10\%. Pande et al. (1994) classified accessions as resistant if infection severity was less than $6 \%$. Approximately $95 \%$ of the accessions would be classified as resistant with 147 accessions in 2007 and 141 accessions in 2008 showing mean infection severities less than $6 \%$. Also, infection severity for the accessions rated as susceptible was significantly lower than the susceptible control genotypes included in the evaluation. Burundi is a region of high annual rainfall (970-1500 mm) and Erpelding (2008) reported that sorghum germplasm accessions from regions experiencing higher annual rainfall were more frequently associated with anthracnose resistance when evaluated in Puerto Rico. Results of this study support the association between the occurrence of anthracnose resistance and high annual rainfall in the country of origin. Climate variation may also be a factor for the variation in disease response observed between the 2007 and 2008 growing seasons. For the 2007 experiment, $40 \mathrm{~mm}$ of rainfall was received after the evaluation conducted 34 days after inoculation compared to $98 \mathrm{~mm}$ of rainfall received after the evaluation conducted 30 days after inoculation for the 2008 experiment. In addition, germplasm collections showing a high frequency of resistant accessions and low infection severities often show greater variation within and between experiments that may result from climatic variation. For this study, 59 accessions were rated as susceptible; however, 51 accessions showed variation in susceptibility across replications and growing seasons with only four accessions showing a mean infection severity greater than $10 \%$. Several studies have shown that climatic conditions can significantly influence anthracnose infection response with greater infection severity observed in regions of higher rainfall (Néya and Le Normand, 1998; Hess et al., 2002; Ngugi et al., 2002). These results suggest that annual rainfall can be used to identify additional germplasm collections from Africa for anthracnose evaluation and this information can aid in the identification of African regions associated with anthracnose resistance for germplasm acquisition. 
Table 1. Disease rating and mean infection severity (\%) for 148 sorghum accessions from the Burundi germplasm collection inoculated with Colletotrichum sublineolum and evaluated for anthracnose resistance during the 2007 and 2008 growing seasons in Isabela, Puerto Rico.

\begin{tabular}{|c|c|c|c|c|}
\hline \multirow[b]{2}{*}{ Accession $^{1}$} & \multicolumn{2}{|c|}{2007} & \multicolumn{2}{|c|}{2008} \\
\hline & Disease Rating $^{2}$ & Disease Severity $^{3}$ & Disease Rating & Disease Severity \\
\hline PI 496273 & 2 & $0.0 \mathrm{a}$ & 2 & $0.0 \mathrm{a}$ \\
\hline PI 496275 & 2 & $0.0 \mathrm{a}$ & 2 & $0.0 \mathrm{a}$ \\
\hline PI 496277 & 2 & $0.0 \mathrm{a}$ & 2 & $0.0 \mathrm{a}$ \\
\hline PI 496279 & 2 & $0.0 \mathrm{a}$ & 2 & $0.0 \mathrm{a}$ \\
\hline PI 496280 & 2 & $0.0 \mathrm{a}$ & 2 & $0.0 \mathrm{a}$ \\
\hline PI 496281 & 2 & $0.0 \mathrm{a}$ & 2 & $0.0 \mathrm{a}$ \\
\hline PI 496282 & 2 & $0.0 \mathrm{a}$ & 2 & $0.0 \mathrm{a}$ \\
\hline PI 496285 & 2 & $0.0 \mathrm{a}$ & 2 & $0.0 \mathrm{a}$ \\
\hline PI 496286 & 2 & $0.0 \mathrm{a}$ & 2 & $0.0 \mathrm{a}$ \\
\hline PI 496288 & 2 & $0.0 \mathrm{a}$ & 2 & $0.0 \mathrm{a}$ \\
\hline PI 496289 & 2 & $0.0 a$ & 2 & $0.0 \mathrm{a}$ \\
\hline PI 496293 & 2 & $0.0 \mathrm{a}$ & 2 & $0.0 \mathrm{a}$ \\
\hline PI 496294 & 2 & $0.0 \mathrm{a}$ & 2 & $0.0 \mathrm{a}$ \\
\hline PI 496297 & 2 & $0.0 \mathrm{a}$ & 2 & $0.0 \mathrm{a}$ \\
\hline PI 496300 & 2 & $0.0 \mathrm{a}$ & 2 & $0.0 \mathrm{a}$ \\
\hline PI 496303 & 2 & $0.0 \mathrm{a}$ & 2 & $0.0 \mathrm{a}$ \\
\hline PI 496304 & 2 & $0.0 \mathrm{a}$ & 2 & $0.0 \mathrm{a}$ \\
\hline PI 496305 & 2 & $0.0 a$ & 2 & $0.0 \mathrm{a}$ \\
\hline PI 496306 & 2 & $0.0 \mathrm{a}$ & 2 & $0.0 \mathrm{a}$ \\
\hline PI 496307 & 2 & $0.0 a$ & 2 & $0.0 \mathrm{a}$ \\
\hline PI 496308 & 2 & $0.0 \mathrm{a}$ & 2 & $0.0 \mathrm{a}$ \\
\hline PI 496309 & 2 & $0.0 \mathrm{a}$ & 2 & $0.0 \mathrm{a}$ \\
\hline PI 496310 & 2 & $0.0 \mathrm{a}$ & 2 & $0.0 \mathrm{a}$ \\
\hline PI 496311 & 2 & $0.0 \mathrm{a}$ & 2 & $0.0 \mathrm{a}$ \\
\hline PI 496312 & 2 & $0.0 \mathrm{a}$ & 2 & $0.0 \mathrm{a}$ \\
\hline PI 496313 & 2 & $0.0 a$ & 2 & $0.0 \mathrm{a}$ \\
\hline PI 496314 & 2 & $0.0 \mathrm{a}$ & 2 & $0.0 \mathrm{a}$ \\
\hline PI 496315 & 2 & $0.0 \mathrm{a}$ & 2 & $0.0 \mathrm{a}$ \\
\hline PI 496317 & 2 & $0.0 \mathrm{a}$ & 2 & $0.0 \mathrm{a}$ \\
\hline PI 496318 & 2 & $0.0 \mathrm{a}$ & 2 & $0.0 \mathrm{a}$ \\
\hline PI 496319 & 2 & $0.0 a$ & 2 & $0.0 \mathrm{a}$ \\
\hline PI 496320 & 2 & $0.0 \mathrm{a}$ & 2 & $0.0 \mathrm{a}$ \\
\hline PI 496321 & 2 & $0.0 \mathrm{a}$ & 2 & $0.0 \mathrm{a}$ \\
\hline PI 496324 & 2 & $0.0 \mathrm{a}$ & 2 & $0.0 \mathrm{a}$ \\
\hline PI 496325 & 2 & $0.0 \mathrm{a}$ & 2 & $0.0 \mathrm{a}$ \\
\hline PI 496326 & 2 & $0.0 \mathrm{a}$ & 2 & $0.0 \mathrm{a}$ \\
\hline PI 496327 & 2 & $0.0 \mathrm{a}$ & 2 & $0.0 \mathrm{a}$ \\
\hline PI 496330 & 2 & $0.0 \mathrm{a}$ & 2 & $0.0 \mathrm{a}$ \\
\hline PI 496331 & 2 & $0.0 \mathrm{a}$ & 2 & $0.0 \mathrm{a}$ \\
\hline PI 496332 & 2 & $0.0 \mathrm{a}$ & 2 & $0.0 \mathrm{a}$ \\
\hline PI 496335 & 2 & $0.0 \mathrm{a}$ & 2 & $0.0 \mathrm{a}$ \\
\hline PI 496337 & 2 & $0.0 a$ & 2 & $0.0 \mathrm{a}$ \\
\hline PI 496338 & 2 & $0.0 a$ & 2 & $0.0 \mathrm{a}$ \\
\hline PI 496339 & 2 & $0.0 a$ & 2 & $0.0 \mathrm{a}$ \\
\hline PI 496340 & 2 & $0.0 \mathrm{a}$ & 2 & $0.0 \mathrm{a}$ \\
\hline PI 496341 & 2 & $0.0 \mathrm{a}$ & 2 & $0.0 \mathrm{a}$ \\
\hline PI 496342 & 2 & $0.0 \mathrm{a}$ & 2 & $0.0 \mathrm{a}$ \\
\hline PI 496343 & 2 & $0.0 a$ & 2 & $0.0 \mathrm{a}$ \\
\hline PI 496344 & 2 & $0.0 \mathrm{a}$ & 2 & $0.0 \mathrm{a}$ \\
\hline PI 496345 & 2 & $0.0 a$ & 2 & $0.0 a$ \\
\hline PI 496346 & 2 & $0.0 \mathrm{a}$ & 2 & $0.0 \mathrm{a}$ \\
\hline PI 496348 & 2 & $0.0 \mathrm{a}$ & 2 & $0.0 \mathrm{a}$ \\
\hline PI 496349 & 2 & $0.0 a$ & 2 & $0.0 \mathrm{a}$ \\
\hline PI 496354 & 2 & $0.0 a$ & 2 & $0.0 \mathrm{a}$ \\
\hline PI 496358 & 2 & $0.0 \mathrm{a}$ & 2 & $0.0 \mathrm{a}$ \\
\hline
\end{tabular}




\begin{tabular}{|c|c|c|c|c|}
\hline PI 496359 & 2 & $0.0 a$ & 2 & $0.0 \mathrm{a}$ \\
\hline PI 496364 & 2 & $0.0 a$ & 2 & $0.0 \mathrm{a}$ \\
\hline PI 496365 & 2 & $0.0 \mathrm{a}$ & 2 & $0.0 \mathrm{a}$ \\
\hline PI 496366 & 2 & $0.0 a$ & 2 & $0.0 a$ \\
\hline PI 527541 & 2 & $0.0 \mathrm{a}$ & 2 & $0.0 \mathrm{a}$ \\
\hline PI 527542 & 2 & $0.0 a$ & 2 & $0.0 \mathrm{a}$ \\
\hline PI 527543 & 2 & $0.0 a$ & 2 & $0.0 \mathrm{a}$ \\
\hline PI 527545 & 2 & $0.0 a$ & 2 & $0.0 \mathrm{a}$ \\
\hline PI 527546 & 2 & $0.0 a$ & 2 & $0.0 \mathrm{a}$ \\
\hline PI 527547 & 2 & $0.0 a$ & 2 & $0.0 a$ \\
\hline PI 527548 & 2 & $0.0 \mathrm{a}$ & 2 & $0.0 \mathrm{a}$ \\
\hline PI 527550 & 2 & $0.0 \mathrm{a}$ & 2 & $0.0 \mathrm{a}$ \\
\hline PI 527553 & 2 & $0.0 a$ & 2 & $0.0 \mathrm{a}$ \\
\hline PI 527554 & 2 & $0.0 a$ & 2 & $0.0 a$ \\
\hline PI 527555 & 2 & $0.0 \mathrm{a}$ & 2 & $0.0 \mathrm{a}$ \\
\hline PI 527556 & 2 & $0.0 a$ & 2 & $0.0 a$ \\
\hline PI 527557 & 2 & $0.0 a$ & 2 & $0.0 \mathrm{a}$ \\
\hline PI 562065 & 2 & $0.0 a$ & 2 & $0.0 \mathrm{a}$ \\
\hline PI 562066 & 2 & $0.0 a$ & 2 & $0.0 \mathrm{a}$ \\
\hline PI 562067 & 2 & $0.0 \mathrm{a}$ & 2 & $0.0 \mathrm{a}$ \\
\hline PI 562068 & 2 & $0.0 a$ & 2 & $0.0 \mathrm{a}$ \\
\hline PI 562071 & 2 & $0.0 \mathrm{a}$ & 2 & $0.0 \mathrm{a}$ \\
\hline PI 562075 & 2 & $0.0 \mathrm{a}$ & 2 & $0.0 \mathrm{a}$ \\
\hline PI 562076 & 2 & $0.0 a$ & 2 & $0.0 a$ \\
\hline PI 562078 & 2 & $0.0 a$ & 2 & $0.0 \mathrm{a}$ \\
\hline PI 562080 & 2 & $0.0 \mathrm{a}$ & 2 & $0.0 \mathrm{a}$ \\
\hline PI 562085 & 2 & $0.0 a$ & 2 & $0.0 \mathrm{a}$ \\
\hline PI 562087 & 2 & $0.0 a$ & 2 & $0.0 \mathrm{a}$ \\
\hline PI 585573 & 2 & $0.0 a$ & 2 & $0.0 a$ \\
\hline PI 585574 & 2 & $0.0 a$ & 2 & $0.0 \mathrm{a}$ \\
\hline PI 585576 & 2 & $0.0 a$ & 2 & $0.0 \mathrm{a}$ \\
\hline PI 585577 & 2 & $0.0 a$ & 2 & $0.0 a$ \\
\hline PI 585579 & 2 & $0.0 \mathrm{a}$ & 2 & $0.0 \mathrm{a}$ \\
\hline PI 585580 & 2 & $0.0 a$ & 2 & $0.0 \mathrm{a}$ \\
\hline PI 496301 & 2 & $0.0 a$ & 21214 & $0.1 a$ \\
\hline PI 496322 & 2 & $0.0 a$ & 21214 & $0.1 a$ \\
\hline PI 496360 & 2 & $0.0 \mathrm{a}$ & $2 \backslash 2 \backslash 4$ & $0.1 a$ \\
\hline PI 562086 & 2 & $0.0 a$ & 21214 & $0.1 a$ \\
\hline PI 496270 & 2 & $0.0 \mathrm{a}$ & 21214 & $0.2 a$ \\
\hline PI 496302 & 2 & $0.0 a$ & 21214 & $0.2 a$ \\
\hline PI 496316 & 2 & $0.0 a$ & 21214 & $0.2 a$ \\
\hline PI 496328 & 2 & $0.0 \mathrm{a}$ & $212 \backslash 4$ & $0.2 a$ \\
\hline PI 496333 & 2 & $0.0 a$ & $212 \backslash 4$ & $0.2 a$ \\
\hline PI 496287 & 2 & $0.0 \mathrm{a}$ & 21214 & $0.3 a$ \\
\hline PI 496295 & 2 & $0.0 a$ & 21214 & $0.3 a$ \\
\hline PI 496329 & 2 & $0.0 a$ & $212 \backslash 4$ & $0.3 a$ \\
\hline PI 562074 & 2 & $0.0 a$ & 21214 & $0.3 a$ \\
\hline PI 496361 & 2 & $0.0 \mathrm{a}$ & $214 \backslash 4$ & $0.3 a$ \\
\hline PI 527544 & 2 & $0.0 \mathrm{a}$ & 21414 & $0.3 a$ \\
\hline PI 562073 & 2 & $0.0 a$ & 21414 & $0.3 a$ \\
\hline PI 562069 & 2 & $0.0 a$ & $214 \backslash 4$ & $0.4 a$ \\
\hline PI 562081 & 2 & $0.0 a$ & $214 \backslash 4$ & $0.5 a$ \\
\hline PI 562082 & 2 & $0.0 a$ & $214 \backslash 4$ & $0.5 a$ \\
\hline PI 585578 & 2 & $0.0 a$ & 21414 & $0.5 a$ \\
\hline PI 496283 & 2 & $0.0 \mathrm{a}$ & 21414 & $0.7 a$ \\
\hline PI 562077 & 2 & $0.0 \mathrm{a}$ & 21414 & $0.7 a$ \\
\hline PI 562084 & 2 & $0.0 a$ & 21414 & $1.0 \mathrm{a}$ \\
\hline PI 527549 & 21214 & $0.2 a b$ & 21214 & $0.1 a$ \\
\hline PI 527552 & $212 \backslash 4$ & $0.2 a b$ & $2 \backslash 2 \backslash 4$ & $0.2 a$ \\
\hline PI 562083 & $212 \backslash 4$ & $0.2 a b$ & 21214 & $0.2 a$ \\
\hline
\end{tabular}




\begin{tabular}{|c|c|c|c|c|}
\hline PI 496357 & $212 \backslash 4$ & $0.2 a b$ & $214 \backslash 4$ & $0.5 a$ \\
\hline PI 585581 & $212 \backslash 4$ & $0.2 \mathrm{ab}$ & $2 \backslash 4 \backslash 4$ & $0.5 a$ \\
\hline PI 496334 & 21214 & $0.3 a b$ & $2 \backslash 4 \backslash 4$ & $0.7 a$ \\
\hline PI 496363 & 4 & $2.7 a b$ & $2 \backslash 4 \backslash 4$ & $1.8 \mathrm{a}$ \\
\hline PI 496347 & 2 & $0.0 \mathrm{a}$ & 4 & $0.4 \mathrm{a}$ \\
\hline PI 562079 & 2 & $0.0 a$ & 4 & $0.4 a$ \\
\hline PI 496355 & 2 & $0.0 \mathrm{a}$ & 4 & $0.5 a$ \\
\hline PI 496356 & 2 & $0.0 a$ & 4 & $0.5 a$ \\
\hline PI 496291 & 2 & $0.0 a$ & 4 & $1.3 a$ \\
\hline PI 496269 & 2 & $0.0 a$ & 4 & $2.2 a$ \\
\hline PI 562072 & 2 & $0.0 a$ & 4 & $2.2 \mathrm{a}$ \\
\hline PI 585575 & 2 & $0.0 a$ & 4 & $2.2 a$ \\
\hline PI 496271 & $2 \backslash 4 \backslash 4$ & $4.0 a b$ & 4 & $0.7 a$ \\
\hline PI 496336 & $2 \backslash 4 \backslash 4$ & $0.5 a b$ & 4 & $0.7 a$ \\
\hline PI 496351 & $2 \backslash 4 \backslash 4$ & $0.5 a b$ & 4 & $0.7 a$ \\
\hline PI 496284 & $214 \backslash 4$ & $0.2 a b$ & 4 & $1.0 \mathrm{a}$ \\
\hline PI 496292 & 21214 & $0.2 a b$ & 4 & $1.2 \mathrm{a}$ \\
\hline PI 585582 & $212 \backslash 4$ & $0.2 a b$ & 4 & $2.0 \mathrm{a}$ \\
\hline PI 496278 & 21214 & $0.7 a b$ & 4 & $2.2 a$ \\
\hline PI 496350 & $2 \backslash 4 \backslash 4$ & $0.5 a b$ & 4 & $2.2 a$ \\
\hline PI 496298 & $214 \backslash 4$ & $0.7 a b$ & 4 & $2.5 a$ \\
\hline PI 496274 & 21414 & $0.5 a b$ & 4 & $3.8 a$ \\
\hline PI 496352 & $2 \backslash 4 \backslash 4$ & $0.3 a b$ & 4 & $3.8 a$ \\
\hline PI 496353 & 4 & $0.5 a b$ & 4 & $1.2 \mathrm{a}$ \\
\hline PI 496299 & 4 & $0.8 a b$ & 4 & $1.7 a$ \\
\hline PI 496276 & $2 \backslash 4 \backslash 4$ & $0.5 a b$ & 4 & $5.2 a b$ \\
\hline PI 496296 & $214 \backslash 4$ & $1.8 \mathrm{ab}$ & 4 & $6.0 \mathrm{ab}$ \\
\hline PI 496272 & 4 & $1.3 a b$ & 4 & $6.7 a b c$ \\
\hline PI 585572 & 4 & $1.0 a b$ & 4 & $8.3 a b c$ \\
\hline PI 527551 & 4 & $5.7 a b$ & 4 & $15.0 \mathrm{bc}$ \\
\hline PI 496323 & 4 & $7.0 \mathrm{~b}$ & 4 & $16.7 \mathrm{~cd}$ \\
\hline PI 496362 & 4 & $21.7 \mathrm{c}$ & 4 & $16.7 \mathrm{~cd}$ \\
\hline PI 496290 & 4 & $4.3 a b$ & $4 \backslash 5 \backslash 5$ & 26.7de \\
\hline NSL 4025 & 2 & $0.0 \mathrm{a}$ & 2 & $0.0 \mathrm{a}$ \\
\hline PI 533794 & 2 & $0.0 a$ & 2 & $0.0 a$ \\
\hline PI 533991 & 2 & $0.0 \mathrm{a}$ & 2 & $0.0 \mathrm{a}$ \\
\hline PI 595735 & 2 & $0.0 \mathrm{a}$ & 2 & $0.0 \mathrm{a}$ \\
\hline PI 534131 & $212 \backslash 4$ & $0.2 a b$ & 2 & $0.0 \mathrm{a}$ \\
\hline PI 561472 & 5 & $1.7 a b$ & 5 & $8.3 a b c$ \\
\hline PI 564163 & 5 & $30.0 d$ & 5 & $30.0 \mathrm{e}$ \\
\hline PI 534157 & 5 & $36.7 d$ & 5 & $46.7 f$ \\
\hline PI 211633 & 5 & $76.7 \mathrm{e}$ & 5 & $76.7 \mathrm{~g}$ \\
\hline PI 533772 & 5 & $70.0 \mathrm{e}$ & 5 & $86.7 \mathrm{gh}$ \\
\hline PI 173112 & 5 & $86.7 f$ & 5 & $90.0 \mathrm{~h}$ \\
\hline PI 609251 & 5 & $90.0 f$ & 5 & $90.0 \mathrm{~h}$ \\
\hline \multicolumn{5}{|c|}{ 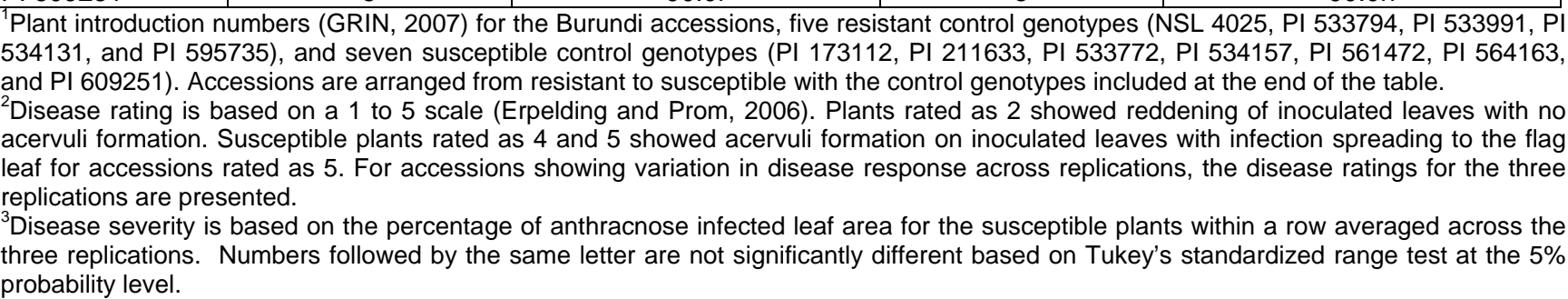 } \\
\hline
\end{tabular}

Disclaimer: Mention of trade names or commercial products in this publication is solely for the purpose of providing specific information and does not imply recommendations or endorsement by the U.S. Department of Agriculture. 


\section{REFERENCES}

Ali, M.E.K., Warren, H.L. and Latin, R.X. (1987). Relationship between anthracnose leaf blight and losses in grain yield of sorghum. Plant Dis. 71:803806.

Crouch, J.A., Clarke, B.B. and Hillman, B.I. (2006). Unraveling evolutionary relationships among the divergent lineages of Colletotrichum causing anthracnose disease in turfgrass and corn. Phytopathology 96:46-50.

Erpelding, J.E. (2008). Field evaluation of anthracnose disease response for the sorghum germplasm collection from the Kayes region of Mali. Trop. Subtrop. Agroecosyst. 8:291-296.

Erpelding, J.E. and Prom, L.K. (2006). Variation for anthracnose resistance within the sorghum germplasm collection from Mozambique, Africa. Plant Pathol. J. 5:28-34

Erpelding, J.E. and Wang, M.L. (2007). Response to anthracnose infection for a random selection of sorghum germplasm. Plant Pathol. J. 6:127-133.

GRIN (2007). USDA-ARS National Genetic Resources Program, Germplasm Resources Information Network (GRIN). Online database. National Germplasm Resources Laboratory, Beltsville, MD, USA, 5 June 2007, http://www.ars-grin.gov/.

Hess, D.E., Bandyopadhyay, R. and Sissoko, I. (2002). Pattern analysis of sorghum genotype $x$ environment interaction for leaf, panicle, and grain anthracnose in Mali. Plant Dis. 86:1374-1382.
Marley, P.S., Thakur, R.P. and Ajayi, O. (2001). Variation among foliar isolates of Colletotrichum sublineolum of sorghum in Nigeria. Field Crops Res. 69:133-142.

Néya, A. and Le Normand, M. (1998). Responses of sorghum genotypes to leaf anthracnose (Colletotrichum graminicola) under field conditions in Burkina Faso. Crop Prot. 17:47-53.

Ngugi, H.K., King, S.B., Abayo, G.O. and Reddy, Y.V.R. (2002). Prevalence, incidence, and severity of sorghum diseases in western Kenya. Plant Dis. 86:6570.

Pande, S., Thakur, R.P., Karunakar, R.I., Bandyopadhyay, R. and Reddy, B.V.S. (1994). Development of screening methods and identification of stable resistance to anthracnose in sorghum. Field Crops Res. 38:157-166.

Thakur, R.P. and Mathur, K. (2000). Anthracnose. In: Frederiksen, R.A. and Odvody, G.N. (Eds.). Compendium of Sorghum Diseases, The American Phytopathological Society, St. Paul, MN, pp 10-12.

Thomas, M.D., Sissoko, I. and Sacko, M. (1996). Development of leaf anthracnose and its effect on yield and grain weight of sorghum in West Africa. Plant Dis. 80:151-153.

Valério, H.M., Resende, M.A., Weikert-Oliveira, R.C.B. and Casela, C.R. (2005). Virulence and molecular diversity in Colletotrichum graminicola from Brazil. Mycopathologia 159:449-459. 